Hong, S. -Y., H. -S. Lin, Y. -H. Sun, and J. -S. Tsai. 2021. Factors affecting intentional bird poisoning on bean farms in Taiwan: seeding methods and the presence of adjoining duck farms matter. Avian Conservation and Ecology 16(2):15. https://doi.org/10.5751/ACE-01954-160215

Copyright (C) 2021 by the author(s). Published here under license by the Resilience Alliance.

Research Paper

\title{
Factors affecting intentional bird poisoning on bean farms in Taiwan: seeding methods and the presence of adjoining duck farms matter
}

\author{
Shiao-Yu Hong ${ }^{1}$, Hui-Shan Lin ${ }^{1,2}$, Yuan-Hsun Sun ${ }^{1}$ and Jo-Szu Tsai ${ }^{3}$ \\ ${ }^{1}$ Institute of Wildlife Conservation, College of Veterinary Medicine, National Pingtung University of Science and Technology, \\ ${ }^{2}$ Graduate Institute of Bioresources, National Pingtung University of Science and Technology, ${ }^{3}$ Department of Biological \\ Resources, National Chiayi University
}

\begin{abstract}
Intentional poisoning is a common practice to reduce bird damage to agricultural crops. Understanding the extent, distribution, and influencing factors of such incidents is key to reducing poisoning of farmland birds and scavengers which are threatened via secondary poisoning. We recruited volunteers to look for dead birds in red bean (Vigna angularis) farms during the seeding period in autumn 2016. A total of 5,441 fields were surveyed, and 51 bird poisoning incidents were identified. We recorded 1,995 dead birds during the survey $(39.1 \pm 29.7$ per incident \pm SD), mostly seed-eating birds. We tested two possible factors influencing the practice of intentional poisoning: seeding methods and whether the red bean farm was adjacent to duck farms. Among three seeding methods, broadcast seeding does not cover the seeds with soils and resulted in a significantly higher proportion of bird poisoning incidents when compared to the whole study area. However, when red bean farms were adjacent to the duck farms, there were no differences in the percentage of poisoning incidents among seeding methods but the number of dead birds was two times higher compared to incidents that were not adjacent to the duck farms. We suspect that birds congregating at duck farms resulted in neighboring farmers taking anti-bird measures, regardless of seeding methods. We map bird poisoning hot spots and provide evidence that changing seeding method and limiting the number of wild birds congregating near duck farms would help reduce bird damage and intentional bird poisoning on red bean farms. Finally, we demonstrated that citizen scientists can make a significant contribution to conservation.
\end{abstract}

\section{Facteurs qui affectent l'empoisonnement intentionnel des oiseaux dans les exploitations de haricots à Taiwan : les méthodes d'ensemencement et la proximité d'élevages de canards jouent un rôle}

RÉSUMÉ. L'empoisonnement intentionnel est une pratique courante pour réduire les dommages causés par les oiseaux aux récoltes agricoles. La compréhension de l'étendue, de la répartition et des facteurs responsables de tels incidents est essentielle pour réduire l'empoisonnement des oiseaux des champs et des charognards qui sont menacés par l'empoisonnement secondaire. Nous avons recruté des volontaires pour rechercher des oiseaux morts sur des exploitations de haricots rouges du Japon (Vigna angularis) pendant la période d'ensemencement à l'automne 2016. En tout, 5441 champs ont été observés et 51 incidents d'empoisonnement d'oiseaux ont été identifiés. Nous avons enregistré 1995 oiseaux morts pendant cette étude $(39,1 \pm 29,7$ par incident \pm la déviation standard). Il s'agissait principalement d'oiseaux granivores. Nous avons testé deux facteurs susceptibles d'influencer la pratique de l'empoisonnement intentionnel : les méthodes d'ensemencement et la proximité d'élevages de canards. Parmi les trois méthodes d'ensemencement, le semis à la volée ne recouvre pas les graines de terre et a entraîné une proportion nettement supérieure d'incidents d'empoisonnement d'oiseaux par rapport au reste de la zone d'étude. Toutefois, lorsque les exploitations de haricots rouges se trouvaient à proximité d'élevages de canards, on n'a constaté aucune différence dans le pourcentage d'incidents d'empoisonnement entre les différentes méthodes d'ensemencement, mais le nombre d'oiseaux morts était deux fois supérieur à celui que l'on pouvait constater dans des zones qui n'étaient pas adjacentes à des élevages de canards. Nous soupçonnons que les oiseaux se réunissent autour des élevages de canards et que cela a incité les fermiers locaux à prendre des mesures pour tuer les oiseaux, quelles que soient les méthodes d'ensemencement. Nous cartographions les points chauds d'empoisonnement des oiseaux et fournissons des preuves indiquant que le changement de méthodes d'ensemencement et la limitation du nombre d'oiseaux sauvages qui se réunissent autour des élevages de canards contribueraient à réduire les dommages causés par les oiseaux et l'empoisonnement intentionnel sur les exploitations de haricots rouges. Enfin, nous avons démontré que des citoyens scientifiques pouvaient apporter une contribution majeure à la conservation.

Key Words: Black Kite, bird damage, carbofuran, ecological trap, poultry farming, secondary poisoning

\section{INTRODUCTION}

Intentional poisoning of wildlife is a worldwide issue in wildlife conservation, particularly threatening predators and scavengers that are either directly targeted or killed through consuming poisoned prey. The motivations to poison wildlife include illegal hunting, protecting livestock or game species from predators, and protecting crops from pest animals (Berny and Gaillet 2008, Linz et al. 2015, Ogada et al. 2015, Elliott et al. 2016, Hong et al. 2018, Ntemiri et al. 2018, Radhakrishnan 2018, Di Blasio et al. 2020). Agricultural pest control is one of the major reasons that farmers 
use poisoned baits. Understand the factors behind the motivation for poisoning is essential for effective wildlife management in agriculture settings.

One of the most common raptor species in the world, the Black Kite (Milvus migrans) is critically endangered in Taiwan (Fang 2005). Black Kites were originally common throughout Taiwan, but in the 1990s the population declined drastically to less than 200 individuals and the Kite disappeared in most places (Severinghaus et al. 2012). In poisoning cases discovered in recent years, carbofuran and second-generation anticoagulant rodenticides were the main causes of Black Kites death. These chemicals are heavily used to control pest birds and rodents on farmland (Hong et al. 2018, Hong et al. 2019). The Black Kite is the only scavenging raptor in Taiwan and has adapted well to human-modified environments, making them vulnerable to secondary poisoning. Policy adjustments have been made accordingly, including canceling the nationwide anti-rodent campaign in 2015 and banning the use of high carbofuran concentrations in 2017. The number of Black Kite has increased gradually to 709 individuals by 2019 (Lin et al. 2019). However, the threats to Black Kite through secondary poisoning remain.

Carbofuran is an insecticide but was often used to kill avian targets illegally around the world because of its high toxicity to birds (Richards 2012, Berny et al. 2015, Ruiz-Suárez et al. 2015, Kitowski et al. 2020). In Taiwan, deliberately poisoning birds with carbofuran was considered the answer to bird damage problems in some agricultural articles from the early 1980s (Hong et al. 2018). A Facebook group was set up in 2014 to gather more information about bird poisoning incidents on farmland, and a total of 213 incidents, involving at least 4,753 dead birds, were reported via the Facebook group from 2014-2016 (Hong et al. 2018). Mapping intentional and illegal poisoning and investigating factors influencing the magnitude and frequency of such events provide key information to understanding and stopping the poisoning (Mateo-Tomás et al. 2012, Márquez et al. 2013). However, data on poisoning events obtained from unstandardized reports are limited and most incidents go unreported (Berny 2007, Ogada 2014).

The red bean (Vigna angularis) is one of the crops regularly associated with poisoning incidents in Taiwan. To avoid bird damage during the seeding and sprouting stages of red beans, some farmers typically mix carbofuran and grains to reduce the population of pest birds (Hong et al. 2018). Because the red bean producing area (Fig. 1) is also an important foraging area for Black Kites, preventing bird poisoning on red bean farms is a top priority. Several seeding methods reduce bird damage to Soybeans (Glycine max) especially those that involve burying seeds in the soil (Firake et al. 2016). In Taiwan, of the three main seeding methods for red beans, both "large seed drill" and "seeding and plowing" include the practice of covering seeds with soil (Chen 2011). Therefore, we predict the third method, "broadcast seeding", which does not cover the seeds with soil will experience the most damage from birds and result in stronger motivation for farmers to set poisoning baits.

Moreover, we noticed the presence of poultry farms in the red bean production areas, primarily open-air duck farms. In Europe, the presence of poultry and dairy farms was related to higher bird abundance and survival because these facilities provide stable feed and safe nest-sites (Hiron et al. 2013, Salek et al. 2015, Salek et al. 2018). However, large congregations of birds likely result in adjacent farmers taking increased anti-bird measures. Consequently, the presence of duck farms adjacent to red bean farms is hypothesized as a potential factor influencing intentional poisoning incidents.

Fig. 1. The distribution map of bird poisoning incidents in red bean farms of 12 townships in October and November 2016. Black diamonds are incidents in fields adjoining duck farms (within $200 \mathrm{~m}$ ), and hollow diamonds are incidents in fields not adjoining duck farms $(>200 \mathrm{~m})$. Gray lines are survey routes that were recorded by volunteers. Six routes were not recorded.

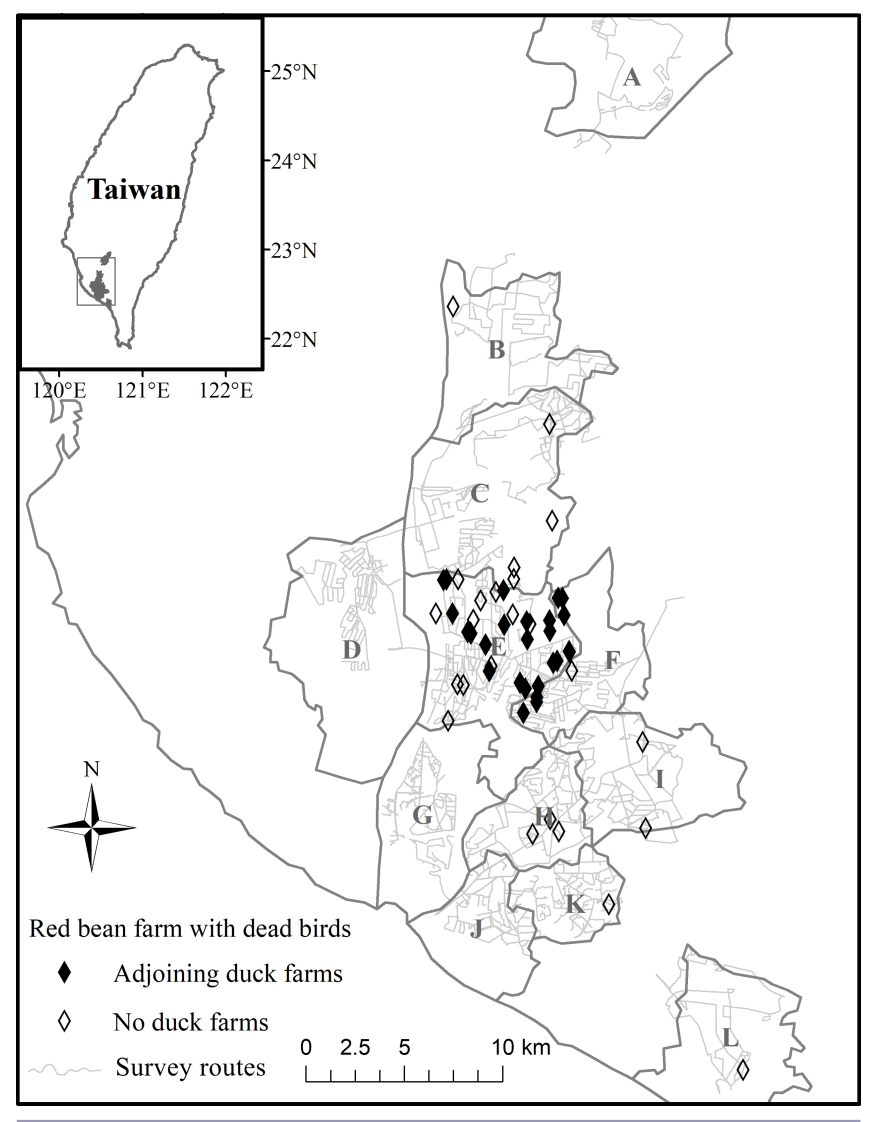

Our overarching goal was to understand the extent, distribution, and influencing factors affecting the practice of intentional poisoning on red bean farms. We investigated the prevalence of intentional poisoning with considerable efforts contributed by volunteers. In particular, we tested the effect of the seeding method used and the presence of adjoining poultry farms as two hypothesized factors that influence the behavior of intentional bird poisoning.

\section{METHODS}

\section{Study area}

The study area was in southern Taiwan, the main red bean producing area (Fig. 1), which is a plain containing both farmlands and villages. In addition to red beans, other major crops 
Table 1. Number of bird poisoning incidents, survey effort, duck farms, and ratio of seeding methods within 12 investigated townships in 2016.

\begin{tabular}{|c|c|c|c|c|c|c|c|c|}
\hline \multirow{2}{*}{$\begin{array}{l}\text { Township } \\
\text { code }\end{array}$} & \multirow{2}{*}{$\begin{array}{l}\text { Area of red } \\
\text { bean }(\mathrm{ha})^{\dagger}\end{array}$} & \multirow{2}{*}{$\begin{array}{c}\text { Bird } \\
\text { poisoning } \\
\text { incidents }\end{array}$} & \multirow{2}{*}{$\begin{array}{c}\text { Fields } \\
\text { examined }\end{array}$} & \multirow{2}{*}{$\begin{array}{c}\text { Survey ratio } \\
(\%)^{*}\end{array}$} & \multirow[t]{2}{*}{ Duck farms } & \multicolumn{3}{|c|}{ Ratio of seeding methods $(\%)$} \\
\hline & & & & & & Large seed drill & $\begin{array}{l}\text { Seeding and } \\
\text { plowing }\end{array}$ & Broadcast seeding \\
\hline A & 1145 & 0 & 540 & 18.9 & 5 & 11.6 & 74.4 & 14.0 \\
\hline B & 185 & 1 & 118 & 25.5 & 17 & 82.2 & 1.7 & 16.1 \\
\hline $\mathrm{C}$ & 513 & 4 & 534 & 41.6 & 0 & 2.5 & 38.1 & 59.4 \\
\hline D & 330 & 0 & 336 & 40.7 & 12 & 74.4 & 18.6 & 7.0 \\
\hline $\mathrm{E}$ & 1475 & 32 & 1080 & 29.3 & 89 & 55.1 & 37.6 & 7.2 \\
\hline $\mathrm{F}$ & 149 & 7 & 301 & 80.8 & 61 & 76.0 & 16.7 & 7.3 \\
\hline $\mathrm{G}$ & 742 & 0 & 861 & 46.4 & 25 & 11.1 & 77.8 & 11.1 \\
\hline $\mathrm{H}$ & 577 & 3 & 625 & 43.3 & 2 & 30.6 & 31.0 & 38.4 \\
\hline I & 159 & 2 & 180 & 45.3 & 12 & 38.9 & 20.8 & 40.3 \\
\hline $\mathbf{J}$ & 252 & 0 & 377 & 59.8 & 1 & 24.8 & 70.6 & 4.6 \\
\hline $\mathrm{K}$ & 207 & 1 & 398 & 76.9 & 5 & 8.6 & 77.4 & 14.0 \\
\hline $\mathrm{L}$ & 175 & 1 & 91 & 20.8 & 4 & 17.6 & 70.6 & 11.8 \\
\hline Total & 5909 & 51 & 5441 & 36.8 & 233 & 32.1 & 49.0 & 18.9 \\
\hline
\end{tabular}

included rice (Oryza sativa), edamame (a cultivar of Glycine max), betel nuts (Areca catechu), and bananas (Musa sapientum). Twelve townships grow red beans, each with more than 140 ha in cultivation (Table 1), accounting for $93.7 \%$ of the total area $(6,305$ ha) used for red bean production in Taiwan in 2016 (Council of Agriculture 2017). There were 233 duck farms (mostly Anas platyrhynchos domesticus) in the study area; $64.4 \%$ were located in townships E and F (Council of Agriculture 2017).

Red beans are usually planted in mid-October, after the second rice crop, and are harvested the following January. Three seeding methods are practiced by red bean farmers: large seed drill, seeding and plowing, and broadcast seeding. The first two methods involve covering the seeds with soil, while the latter does not. The large seed drill plants and covers the seeds at the same time. This method is the most efficient; it reduces the amount of seed needed by $28 \%$ while increasing yield by $20 \%$ compared to broadcast seeding (Chen 2011), a financial benefit to the farmers. However, the large seed drill is expensive and availability is limited. Seeding and then plowing with a small cultivator is an alternative, though it is more labor intensive than the other two methods. The amount of seed needed for this method is similar to broadcast seeding but the yield is slightly less than the method of large seed drill (Chen 2011). Broadcast seeding without plowing is the roughest method. It requires less time and effort from the farmer, but the yield is lower (Chen 2011). The different methods can be distinguished clearly in appearance after seeding (Fig. A1.1).

\section{Investigating bird poisoning incidents}

We posted volunteer recruitment information on the Facebook group, Bird Poison Report, Taiwan (https://www.facebook.com/ groups/1490158747925040/) in September 2016. This group was set up in 2014 to collect data on avian poisoning incidents on farmlands and, as of September 2016, included 3,409 members (Hong et al. 2018). A total of 53 local residents or college students volunteered for the study, and a contact group meeting and a survey briefing were held before the investigation. Each township was divided into two to four small regions according to the size of the township and the density of the red bean farms. There were a total of 31 regions (mean $983 \pm 195$ ha, \pm SD) in our study area and all of them were surveyed. Each small region was assigned to a group ranging in size from one to three people. Volunteers were assigned to small regions near their home range if possible. Their familiarity with the local area allowed the volunteers to decide their own investigation routes. The boundaries of each small region were set up on a shared Google Map, so volunteers were able to navigate routes and identify region boundaries via smartphones.

The investigator typically rode a motorcycle, moving slowly along the farmland roads, and looked for dead birds in the red bean farms. The red bean farms consisted of rectangular fields with clear boundaries, typically $0.3-0.6$ ha (see Fig. A1.2). The long side of a field is $\sim 100 \mathrm{~m}$, and most areas of the fields after seeding are clearly visible. Thus, if there are dead birds in the field they can usually be spotted from the adjacent road. Volunteers did not need to enter the field during investigations. The survey period was between October 5 and November 6, 2016, when red beans were either being sowed or were sprouting. After mid-November red bean plants have grown tall enough to hide the dead birds and limit the reliability of the survey data. Because the planting time varied in different fields, volunteers were asked to survey their small region at least twice during this period to maximize the chance of detecting intentional poisoning incidents. The first of the two surveys was conducted before October 23, and the second had to take place after October 23. Additionally, the surveys were separated by at least one week.

If volunteers encountered dead birds during their survey, they were asked to report the incident to us immediately. We verified every bird mortality incident ourselves which included looking 
for poisoned baits, removing dead birds, recording the seeding method used, and noting whether there are duck farms within $200 \mathrm{~m}$ of the field (Fig. 2). If dead birds were scattered across several fields, it would only be counted as one incident. We considered the presence of poisoned baits (usually small heaps of rice or corn, Fig. A1.3) to be important evidence of intentional poisoning, and birds typically die nearby. Since carbofuran is a very quick-acting poison for birds, small birds die in less than a minute after ingesting a small amount (Richards 2012, Hong et al. 2018). Thus, this pest control method (i.e., heaps of rice or corn laced with carbofuran) often causes a group of dead birds and this was used as part of the criteria for categorizing mortality events. If only one or two dead birds and no suspected poisoned baits were found, the bird mortalities were not considered a poisoning incident (Hong et al. 2018). If there were three or more dead birds and poisoned bait was present, the bird mortalities were considered a poisoning incident. We did not ask volunteers to look for poisoned baits since those baits are small and scattered thus not as obvious as dead birds. In addition, some farmers may use different poison methods to make their baits difficult to identify. If there were three or more dead birds in a field, but we could not find any bait, we collected the liver of one freshly dead bird for multi-pesticide (i.e., 310 pesticides) residue testing following Hong et al. (2018). Chemical analysis was conducted by ABM International Lab Inc. located in Pingtung, Taiwan. Limits of quantification of each pesticide ranged from 0.005 to $0.01 \mathrm{mg} / \mathrm{kg}$.

Fig. 2. (A) The feed in duck farms often attracts a large number of wild birds. (B) A red bean farm adjacent to a duck farm.

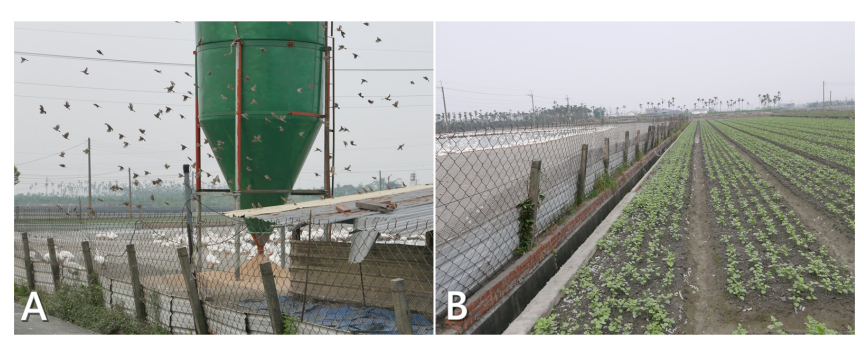

In addition to bird mortality incidents, volunteers were asked to 1) provide their survey routes using a smartphone app such as Endomondo. By checking their routes (.gpx file), the survey effort could be quantified and any missed areas were noted;2) volunteers were asked to record how many red bean fields they surveyed each time. The number of surveyed fields was used to estimate the percentage of red bean farms that were surveyed within each township. Since the volunteers were still familiarizing themselves with the methods and route during the first survey, we expected that the second survey would be more comprehensive. Therefore, only fields counted in the second survey were included in the analyses to avoid double counting; 3) volunteers were also instructed to randomly take pictures of at least 100 fields of the red bean farm while surveying in each region. Based on these pictures (Fig. A1.1), we were able to estimate the proportion of seeding methods used in each township. Volunteers who finished two surveys and provided data successfully received a commemorative T-shirt. We also provided accident insurance for volunteers during their investigation.

\section{Data analysis}

Both first and second survey routes provided by volunteers were checked for mileage and time spent. The number of surveyed fields counted by volunteers was multiplied by 0.4 ha (an approximately average field area) to estimate the surveyed area of each township. The calculated survey area was then divided by the total planting area of red bean farms in that township to estimate the survey ratio $(\%)$.

One important goal of this study was to map distribution and hotspots of bird poisoning incidents; therefore, the method was designed to allow volunteers to investigate a large area in a relatively short period of time. We did not ask volunteers to record the seeding method of each field individually since it was time consuming (i.e., thousands of fields). The seeding method and presence of neighboring duck farms were recorded only in fields where a bird poisoning incident was identified. Because of this trade-off, the sampling unit would not be each surveyed field. Additionally, the planting area and survey effort (i.e., survey ratio) of each small region and township were not equal, so regions and townships would not be compared with each other. Instead, to test the study hypothesis, the proportion of seeding methods in different groups (i.e., adjacent to duck farms or not) of bird poisoning incidents was compared to the whole study area via chi-squared tests as an alternative.

We performed three sets of chi-square tests. The first was the proportion of seeding methods with all bird poisoning incidents comparing to the whole study area. The second and third were to test if an adjoining duck farm was a factor that would affect the behavior of intentional bird poisoning practices of bean farmers. The bird poisoning incidents were then divided into two groups: incidents that were adjacent to duck farms $(<200 \mathrm{~m})$ and incidents that were not adjacent to duck farms. The proportions of seeding methods of these two groups were compared to the whole study area respectively.

When we removed dead birds from fields in each incident, we recorded the species and numbers. To test if the number of dead birds was also affected by seeding methods and the presence of duck farms, a two-way ANOVA was adopted. The sampling unit here was each bird poisoning incident. Statistical tests were performed using SPSS version 25 (IBM Corp.).

\section{RESULTS}

During the investigation, $94.3 \%$ of the 53 volunteers finished two surveys and all 31 small regions were surveyed at least twice. Total mileage was approximately $2,536 \mathrm{~km}$ (mean $31 \pm 20 \mathrm{~km} /$ survey $\pm \mathrm{SD}$ ), and 263 hours (mean $3.3 \pm 1.9 \mathrm{hr} /$ survey $\pm \mathrm{SD}$ ). Six routes were not recorded. A total of 5,441 fields were examined in the second survey, and approximately $36.8 \%$ of all red bean farms in the study area were covered (Table 1).

There were 51 bird poisoning incidents in red bean farms and six incidents in other crops (rice or corn fields). For the incidents in red bean farms, eight were found in the first survey, and 43 were found in the second survey. We removed 1,995 dead birds (mean $39.1 \pm 29.7$ / incident $\pm \mathrm{SD}$, range 5 - 158) consisting of eight species, of which $81.8 \%$ were Eurasian Tree Sparrows (Passer montanus), followed by three species of Columbidae (12.8\% Red 
Collared-Dove Streptopelia tranquebarica, 3.9\% Spotted Dove Streptopelia chinensis, and 1.4\% Rock Pigeon Columba livia). No dead Black Kites were found during the survey. We did not find obvious baits in nine incidents; however, the nine birds analyzed (one from each of the nine incidents) contained detectable concentrations of carbofuran residue (range $0.007-125.3 \mathrm{mg} / \mathrm{kg}$, Table A1.1), indicating all these incidents (despite no obvious poisoned baits) were also associated with intentional poisoning.

In the whole study area, seeding and plowing was the main seeding method for red beans $(49.0 \%)$, followed by the large seed drill $(32.1 \%)$ and broadcast seeding $(18.9 \%)$ (Table 1). In bird poisoning incidents, $14(27.5 \%), 14(27.5 \%)$, and $23(45.1 \%)$ incidents belong to seeding and plowing, large seed drill, and broadcast seeding, respectively. The proportion of poisoning incidents across the three methods was significantly different from the whole study area $(X=26.924, \mathrm{df}=2, p<0.001$, Fig. 3A). For incidents that were not adjacent to duck farms $(n=24)$, the proportion of broadcast seeding raised to $79.2 \%(X=60.445$, df $=2, p<0.001$, Fig. 3B). However, in the 27 incidents adjacent to duck farms, the main seeding method was the large seed drill and showed no difference between incidents and whole study area $(X$ $=1.931, \mathrm{df}=2, p=0.381$, Fig. 3C).

The two-way ANOVA test indicated that the number of dead birds was not affected by seeding methods $\left(\mathrm{F}_{2,45}=0.314, p=0.732\right)$, but was affected by the presence of duck farms $\left(\mathrm{F}_{1,45}=7.452, p\right.$ $<0.01)$. These two factors had no interaction in this test $\left(\mathrm{F}_{2,45}=\right.$ $1.222, p=0.304)$. The number of dead birds was significantly greater in incidents that adjoined duck farms $(51.1 \pm 34.8, \mathrm{n}=$ 27) compared to incidents not adjacent to duck farms (25.6 \pm 14.0 , $\mathrm{n}=24$ ) (Fig. 4).

\section{DISCUSSION}

Red beans are an important and famous crop of the autumn agricultural season in southern Taiwan. In 2014 and 2015, 24 intentional bird poisoning incidents (including multiple incidents at the same locations in different years) were reported from this region to the Facebook group Bird Poison Report, Taiwan (Hong et al. 2018). In this study, with considerable volunteer efforts and a standardized method, we documented an additional 51 incidents and were able to map hot spots of poisoning activity. In addition, our results both provided new insights regarding seeding methods and indicated that the presence of adjoining poultry farms affects the number of intentional bird poisonings and exacerbates the severity of poisoning incidents.

Broadcast seeding was the most common seeding method in bird poisoning incidents. In the incidents not adjoining duck farms, the proportion of broadcast seeding was even higher. Our results indicated that the fields where the other two seeding methods were used (both of which cover seeds with soil) were less likely to have incidents of poisoning. This finding is similar to results from soybean, where covering seeds with soil reduced the extent of birds feeding on the seeds (Firake et al. 2016). We suggest promoting the changing of seeding methods from broadcast seeding to the other two methods to help reducing bird damage of red bean and lower the farmer's motivation for poisoning birds. However, in the incidents adjoining duck farms, the most common seeding method was the large seed drill, and the proportion of the three methods was not different from the whole study area.
Fig. 3. (A) Ratio of seeding methods between total farms and farms with bird poisoning incidents $(n=51)$; (B) ratio of seeding methods between total farms and farms with bird poisoning incidents which did not adjoin the duck farms $(\mathrm{n}=$ 24); (C) ratio of seeding methods between total farms and farms with bird poisoning incidents adjoining the duck farms $(n=27)$.
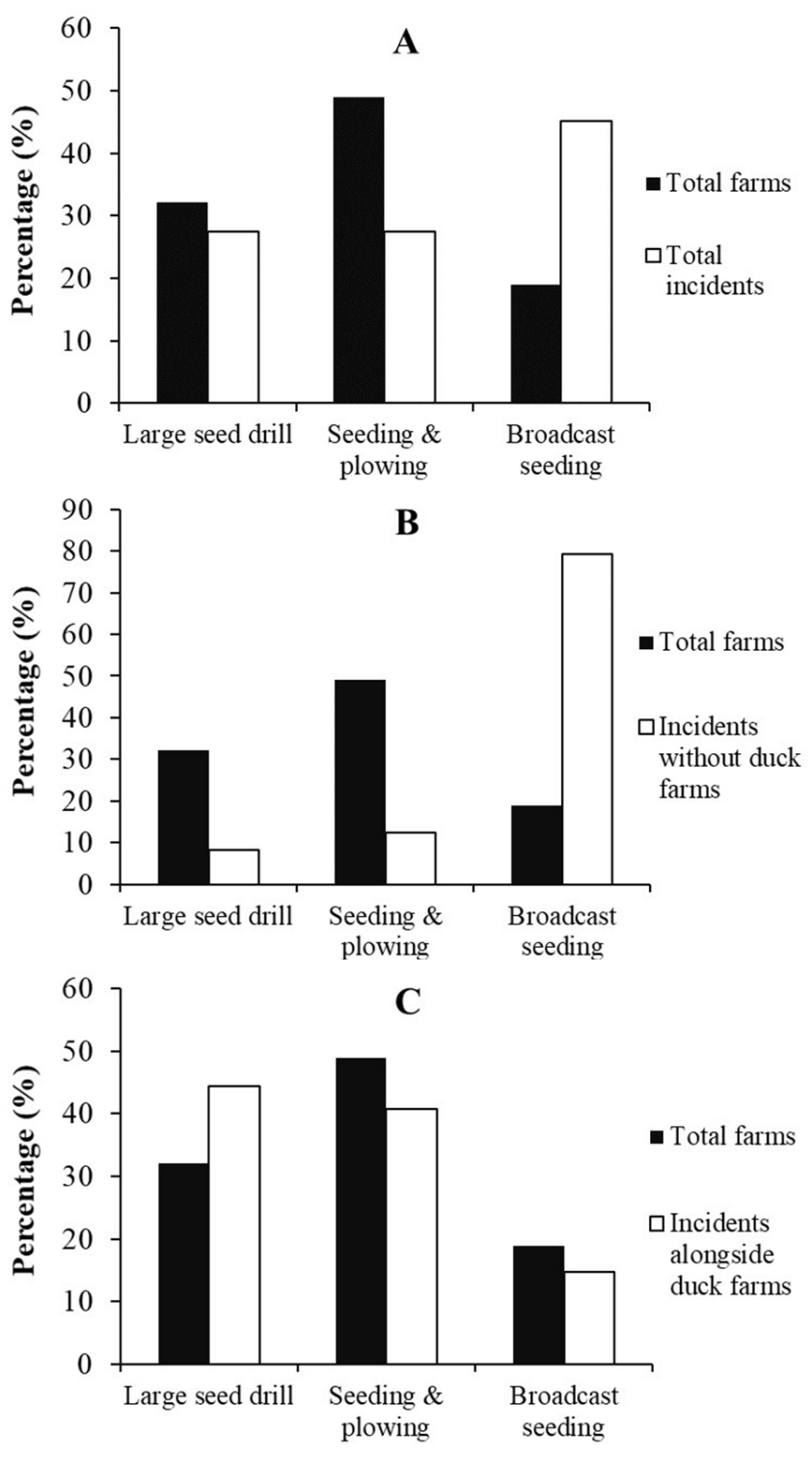

We found that the seeding method effect was not significant in poisoning incidents adjoining duck farms. In addition, the number of dead birds in those incidents was twice as high when compared to incidents without duck farms. This phenomenon is in line with our hypothesis: birds congregating at duck farms resulted in adjoining farmers taking anti-bird measures, regardless of seeding methods. And because of the high density of birds around duck farms, the extent of poisoning incidents was more serious. Over $60 \%$ of duck farms were located in townships 
E and F, which made these two townships hot spots of bird poisoning incidents, despite the fact that the proportion of large seed drill is relatively high in these two townships. Several studies in Europe suggested farmsteads (e.g., poultry and dairy farms) in simplified agricultural landscapes are local bird diversity hotspots and the key factor to support wild bird survival in winter (Hiron et al. 2013, Salek et al. 2015, Salek et al. 2018). In contrast, our study indicated that poultry farms may be functioning as ecological traps presumably due to elevated levels of intentional poisoning by farmers.

Fig. 4. Number of dead birds in poisoning incidents adjacent to duck farms $(n=27)$ and not adjacent to duck farms $(n=24)$.

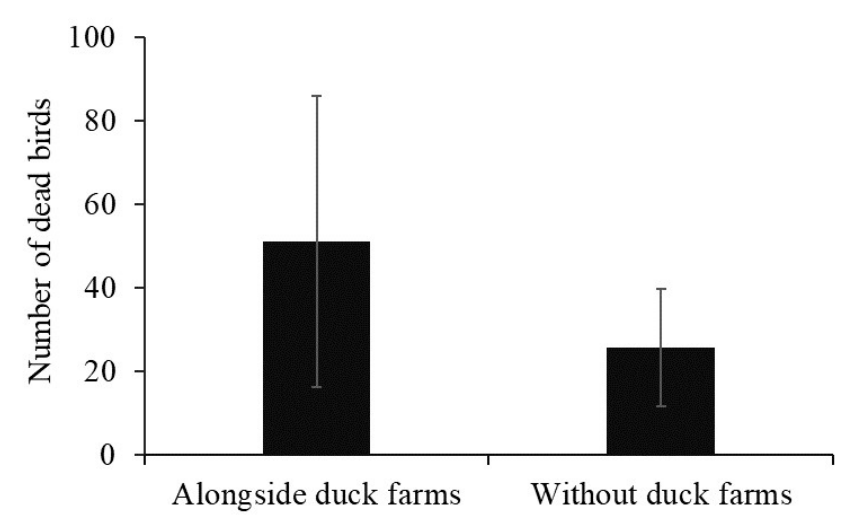

Additionally, the Taiwanese government has implemented regulations requiring poultry farmers to construct bird barriers (i.e., anti-bird nets) around feeders. These regulations were written in response to the risk of spreading avian influenza from wild birds to poultry (Scherer et al. 2011, Burns et al. 2012, Jeong et al. 2014). If poultry farms do not implement bird barrier measures around feeders, the poultry farms will be fined. Based on our observations, the barriers in most duck farms were damaged or had holes, hence the measures were often ineffective. If the barriers were maintained and fewer wild birds congregated at duck farms, surrounding farmers might have less motivation to put out poisoned bait, thereby reducing the chance of bird poisoning incidents at fields near duck farms. Future research is needed to understand the effect of duck farm management on farmland bird abundance, distribution, and survival.

Carbofuran is the most common pesticide to be used for pest bird control in Taiwan. In a study where 29 birds collected from incidents in a variety of crops were tested for pesticides, $96.6 \%$ of them contained carbofuran, and only one bird contained terbufos, another highly toxic insecticide (Hong et al. 2018). This pest bird control method of mixing grains with carbofuran liquids or powders $(37 \%, 40 \%$, or higher concentration) was frequently mentioned in government guidelines published in the 1980s (Hong et al. 2018). Carbofuran is also one of the most common pesticides used to poison wildlife illegally in Europe. It has been completely banned in European Union in 2008 (Berny et al. 2015, RuizSuárez et al. 2015, Ntemiri et al. 2018, Di Blasio et al. 2020). Based on the $\mathrm{LD}_{50}$ value and average body weight, $5 \mathrm{~g}$ of carbofuran product could kill 4,167 Common Kestrels (Falco tinnunculus) (Ruiz-Suárez et al. 2015).
We did not find poisoned baits in nine poisoning incidents. During interviews, some farmers reported using alternative methods for poisoning birds. One method is to treat red bean seeds with carbofuran directly, instead of setting poisoned baits. The other method is that farmers distribute $3 \%$ carbofuran granules in fields. Granular carbofuran was another option to reduce bird damage that was promoted in early agricultural articles in Taiwan (Hong et al. 2018). There is much evidence that carbofuran granules are ingested by birds with lethal consequences (Balcomb 1983, Stafford and Best 1999, Mineau et al. 2011). It is currently controversial whether such killing of pest birds is illegal given that the Taiwanese Wildlife Conservation Act gives farmers the right to protect their crops. However, the two methods of using carbofuran treated seeds and distributing carbofuran granules are illegal because carbofuran is not an approved pesticide for red beans. Therefore, better enforcement of this regulation is another potential pathway to reducing intentional bird poisonings.

Chemical pesticides are serious threats that farmland birds are facing worldwide (Mineau and Whiteside 2013, Costantini 2015, Stanton et al. 2018). Birds may be poisoned deliberately (the case in this study) or victimized unintentionally, for example, with imidacloprid-treated seeds (Millot et al. 2016, Eng et al. 2019). Determining harmful substances and exposure routes is the key to solve the problem. In Taiwan, although carbofuran was introduced as an effective tool to reduce bird damage in the 1980s and continues to date (Hong et al. 2018), public awareness on this issue is still limited. When media reports on bird poisoning incidents, the cause is often described as an overdose of pesticides on crops or ingestion of rat poison. These misconceptions do not help to solve the real problem. In addition, as mentioned above, some farmers did not use typical poison baits or pesticides (i.e., terbufos) which makes it harder to determine the cause of bird death.

The internet community (i.e., a Facebook group) plays an important role in the issue of bird poisoning in Taiwan (Hong et al. 2018). The community can quickly attract the attention of the public and gather people who care about the subject, including scientists. Since volunteers usually have no related background, the survey method must be designed as simply as possible with clear instructions. Some necessary work still needs to be done by the researchers, such as looking for poison baits to determine the cause of each incident, identifying the species of dead birds and counting the number, and sometimes interviewing the farmers. However, in this study we have demonstrated that the inclusion of citizen scientists greatly enhanced our ability to collect the necessary data at a meaningful scale. With careful design and communication, the citizen scientists can play an important role in conservation. One thing should be noted is that there are often different opinions regarding complicated conservation issue on the Internet. When posting the volunteer recruitment information and when interviewing farmers, we emphasized that the purpose of this study was to solve agricultural-wildlife conflicts with a positive mindset, instead of blaming farmers' behavior on intentional bird poisoning.

Cases of secondary poisoning of Black Kites have raised awareness in Taiwan about intentional bird poisoning practices (Hong et al. 2018). These poisonings occur in many kinds of crops which have bird damage problems, not just red beans (Hong et 
al. 2018). Bird damage may occur in different seasons and growth stages as a result of different bird species and may require a variety of solutions depending on the crop. For red beans, the government is promoting the use of large seed drills by providing a subsidy to purchase the equipment. Bird barrier measures also are checked more frequently in duck farms to ensure compliance. In addition, high concentration carbofuran was banned in 2017; only granules with a concentration of $3 \%$ remain available. The newly edited Conservation Action Plan for Black Kites in Taiwan has pointed out that the Black Kite is an indicator species of the health of the agricultural environment, and to improve their survival status may thus contribute to the wellbeing of the whole agricultural ecosystem (Lin et al. 2019). We hope this is a good example of how to solve agricultural-wildlife conflicts while also protecting Black Kites and other farmland birds.

Responses to this article can be read online at: https://www.ace-eco.org/issues/responses.php/1954

\section{Acknowledgments:}

We thank all the volunteers involved in this study. We also thank the ABM International Lab Inc. for conducting chemical analysis as well as Lynn Bryant and Louise Venne for editing the manuscript. The Taiwan Forestry Bureau, Bureau of Animal and Plant Health Inspection and Quarantine, and the Pingtung County Government provided financial and administrative support. No birds were captured for this study. Research complies with regulations of the Wildlife Conservation Act and other related laws in Taiwan.

\section{LITERATURE CITED}

Balcomb, R. 1983. Secondary poisoning of Red-Shouldered Hawks with carbofuran. Journal of Wildlife Management 47:1129-1132. https://doi.org/10.2307/3808175

Berny, P. 2007. Pesticides and the intoxication of wild animals. Journal of veterinary pharmacology and therapeutics 30:93-100. https://doi.org/10.1111/j.1365-2885.2007.00836.x

Berny, P., and J.-R. Gaillet. 2008. Acute poisoning of Red Kites (Milvus milvus) in France: Data from the SAGIR network. Journal of Wildlife Diseases 44:417-426. https://doi.

org/10.7589/0090-3558-44.2.417

Berny, P., L. Vilagines, J. -M. Cugnasse, O. Mastain, J. -Y. Chollet, G. Joncour, and M. Razin. 2015. Vigilance Poison: illegal poisoning and lead intoxication are the main factors affecting avian scavenger survival in the Pyrenees (France). Ecotoxicology and Environmental Safety 118:71-82. https://doi.org/10.1016/j. ecoenv.2015.04.003

Burns, T. E., C. Ribble, C. Stephen, D. Kelton, L. Toews, J. Osterhold, and H. Wheeler. 2012. Use of observed wild bird activity on poultry farms and a literature review to target species as high priority for avian influenza testing in 2 regions of Canada. Canadian Veterinary Journal 53:158. https://pubmed.ncbi.nlm. nih.gov/22851777/
Chen, Y. -J. 2011. Red bean cultivation and rationalized fertilization. Gaoxiong Agricultural Technology Report 107:3-15.

Costantini, D. 2015. Land-use changes and agriculture in the tropics: pesticides as an overlooked threat to wildlife. Biodiversity and Conservation 24:1837-1839. https://doi.org/10.1007/s10531-015-0878-8

Council of Agriculture. 2017. Agricultural Statistics Database. http://agrstat.coa.gov.tw/sdweb/public/inquiry/InquireAdvance.aspx (last accessed 27 February 2019).

Di Blasio, A., S. Bertolini, M. Gili, R. Avolio, M. Leogrande, F. Ostorero, G. Ru, A. Dondo, and S. Zoppi. 2020. Local context and environment as risk factors for acute poisoning in animals in northwest Italy. Science of the Total Environment 709:136016. https://doi.org/10.1016/j.scitotenv.2019.136016

Elliott, J. E., B. A. Rattner, R. F. Shore, and N. W. Van Den Brink. 2016. Paying the pipers: mitigating the impact of anticoagulant rodenticides on predators and scavengers. Bioscience 66:401-407. https://doi.org/10.1093/biosci/biw028

Eng, M. L., B. J. M. Stutchbury, and C. A. Morrissey. 2019. A neonicotinoid insecticide reduces fueling and delays migration in songbirds. Science 365:1177-1180. https://doi.org/10.1126/ science.aaw9419

Fang, W. H. 2005. A Guide to Threatened Birds of Taiwan. Owl Publishing House, Taipei, Taiwan.

Firake, D., G. Behere, and S. Chandra. 2016. An environmentally benign and cost-effective technique for reducing bird damage to sprouting soybean seeds. Field Crops Research 188:74-81. https:// doi.org/10.1016/j.fcr.2016.01.008

Hiron, M., Å. Berg, S. Eggers, and T. Pärt. 2013. Are farmsteads over-looked biodiversity hotspots in intensive agricultural ecosystems? Biological Conservation 159:332-342.

Hong, S. -Y., H. -S. Lin, B. A. Walther, J. -E. Shie, and Y. -H. Sun. 2018. Recent avian poisonings suggest a secondary poisoning crisis of Black Kites during the 1980s in Taiwan. Journal of Raptor Research 52:326-337. https://doi.org/10.3356/JRR-17-40.1

Hong, S. -Y., C. Morrissey, H. -S. Lin, K. -S. Lin, W. -L. Lin, C. T. Yao, T. -E. Lin, F. -T. Chan, and Y. -H. Sun. 2019. Frequent detection of anticoagulant rodenticides in raptors sampled in Taiwan reflects government rodent control policy. Science of the Total Environment 691:1051-1058. https://doi.org/10.1016/j. scitotenv.2019.07.076

Jeong, J., H. -M. Kang, E. -K. Lee, B. -M. Song, Y. -K. Kwon, H. -R. Kim, K.-S. Choi, J. -Y. Kim, H. -J. Lee, and O. -K. Moon. 2014. Highly pathogenic avian influenza virus (H5N8) in domestic poultry and its relationship with migratory birds in South Korea during 2014. Veterinary Microbiology 173:249-257. https://doi. org/10.1016/j.vetmic.2014.08.002

Kitowski, I., R. Łopucki, A. Stachniuk, and E. Fornal. 2020. A pesticide banned in the European Union over a decade ago is still present in raptors in Poland. Environmental Conservation 47:310-314. https://doi.org/10.1017/S037689292000034X

Lin, H. -S., S. -Y. Hong, D. -H. Tsai, J. -W. Zeng, W. Cheng, and J. -E. Shie. 2019. Conservation Action Plan for Black Kites 
(Milvus migrans) in Taiwan, 2019. Forestry Bureau, Agricultural Committee of the Executive Yuan, Taipei, Taiwan.

Linz, G. M., E. H. Bucher, S. B. Canavelli, E. Rodriguez, and M. L. Avery. 2015. Limitations of population suppression for protecting crops from bird depredation: A review. Crop Protection 76:46-52. https://doi.org/10.1016/j.cropro.2015.06.005

Mateo-Tomás, P., P. P. Olea, I. S. Sánchez-Barbudo, and R. Mateo. 2012. Alleviating human-wildlife conflicts: identifying the causes and mapping the risk of illegal poisoning of wild fauna. Journal of Applied Ecology 49:376-385. https://doi.org/10.1111/ j.1365-2664.2012.02119.x

Millot, F., A. Decors, O. Mastain, T. Quintaine, P. Berny, D. Vey, R. Lasseur, and E. Bro. 2016. Field evidence of bird poisonings by imidacloprid-treated seeds: a review of incidents reported by the French SAGIR network from 1995 to 2014. Environmental Science and Pollution Research 24:5469-5485. https://doi. org/10.1007/s11356-016-8272-y

Mineau, P., L. Lyon, and S. McMillin. 2011. Impacts of carbofuran on birds in Canada and the United States. Pages 208-250 in N. Richards, editor. Carbofuran and Wildlife Poisoning: Global Perspectives and Forensic Approaches. John Wiley \& Sons, Inc., Oxford, UK. https://doi.org/10.1002/9781119998532. ch8

Mineau, P., and M. Whiteside. 2013. Pesticide acute toxicity is a better correlate of US grassland bird declines than agricultural intensification. PLoS One 8:e57457. https://doi.org/10.1371/ journal.pone.0057457

Márquez, C., J. M. Vargas, R. Villafuerte, and J. E. Fa. 2013. Risk mapping of illegal poisoning of avian and mammalian predators. Journal of Wildlife Management 77:75-83. https://doi. org/10.1002/jwmg.424

Ntemiri, K., V. Saravia, C. Angelidis, K. Baxevani, M. Probonas, E. Kret, Y. Mertzanis, Y. Iliopoulos, L. Georgiadis, and D. Skartsi. 2018. Animal mortality and illegal poison bait use in Greece. Environmental Monitoring and Assessment 190:488. https://doi. org/10.1007/s10661-018-6838-5

Ogada, D., A. Botha, and P. Shaw. 2015. Ivory poachers and poison: drivers of Africa's declining vulture populations. Oryx 50:593-596. https://doi.org/10.1017/S0030605315001209

Ogada, D. L. 2014. The power of poison: pesticide poisoning of Africa's wildlife. Annals of the New York Academy of Sciences 1322:1-20. https://doi.org/10.1111/nyas. 12405

Radhakrishnan, S. 2018. A note on wildlife poisoning cases from Kerala, South India. European Journal of Wildlife Research 64:58. https://doi.org/10.1007/s10344-018-1218-6
Richards, N. 2012. Carbofuran and wildlife poisoning: global perspectives and forensic approaches. Wiley-Blackwell, UK. https://doi.org/10.1002/9781119998532

Ruiz-Suárez, N., L. D. Boada, L. A. Henríquez-Hernández, F. González-Moreo, A. Suárez-Pérez, M. Camacho, M. Zumbado, M. Almeida-González, M. del Mar Travieso-Aja, and O. P. Luzardo. 2015. Continued implication of the banned pesticides carbofuran and aldicarb in the poisoning of domestic and wild animals of the Canary Islands (Spain). Science of the Total Environment 505:1093-1099. https://doi.org/10.1016/j. scitotenv.2014.10.093

Salek, M., M. Bazant, and M. Zmihorski. 2018. Active farmsteads are year-round strongholds for farmland birds. Journal of Applied Ecology 55:1908-1918. https://doi. org/10.1111/1365-2664.13093

Salek, M., J. Havlicek, J. Riegert, M. Nespor, R. Fuchs, and M. Kipson. 2015. Winter density and habitat preferences of three declining granivorous farmland birds: The importance of the keeping of poultry and dairy farms. Journal for Nature Conservation 24:10-16. https://doi.org/10.1016/j.jnc.2015.01.004

Scherer, A. L., J. D. M. Scherer, M. V. Petry, and M. Sander. 2011. Occurrence and interaction of wild birds at poultry houses in southern Brazil. Revista Brasileira de Ornitologia 19:74-79.

Severinghaus, L. L., T.-S. Ding, W.-H. Fang, W.-H. Lin, M.-C. Tsai, and C.-W. Yen. 2012. The Avifauna of Taiwan. (2nd edition). Forestry Bureau, Council of Agriculture, Taipei, Taiwan.

Stafford, T. R., and L. B. Best. 1999. Bird response to grit and pesticide granule characteristics: implications for risk assessment and risk reduction. Environmental Toxicology and Chemistry 18:722-733. https://doi.org/10.1002/etc.5620180419

Stanton, R., C. Morrissey, and R. Clark. 2018. Analysis of trends and agricultural drivers of farmland bird declines in North America: A review. Agriculture, Ecosystems \& Environment 254:244-254. https://doi.org/10.1016/j.agee.2017.11.028
Editor-in-Chief: Alexander L.Bond Subject Editor: Kevin RBurgio
Sponsored by the Society of Canadian Ornithologists and Birds Canada

Parrainée par la Société des ornithologistes du Canada et Oiseaux Canada

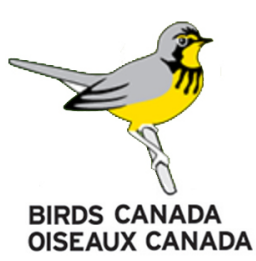




\section{Appendix 1.}

2 Table A1.1 In nine Red Bean farms without obvious bait, one dead bird from each

3 farm was tested for pesticide residue. We detected carbofuran in all nine birds with

4 concentrations for each bird listed below.

\begin{tabular}{|c|c|c|c|}
\hline No. & Species $^{\dagger}$ & Township & Carbofuran $(\mathrm{mg} / \mathrm{kg})$ \\
\hline 1 & Spotted Dove & $\mathrm{C}$ & 0.007 \\
\hline 2 & Red Collared-Dove & $\mathrm{E}$ & 1.463 \\
\hline 3 & Eurasian Tree Sparrow & $\mathrm{E}$ & 0.184 \\
\hline 4 & Light-vented Bulbul & E & 125.2 \\
\hline 5 & Eurasian Tree Sparrow & E & 3.089 \\
\hline 6 & Eurasian Tree Sparrow & $\mathrm{F}$ & 4.633 \\
\hline 7 & Red Collared-Dove & $\mathrm{F}$ & 13.25 \\
\hline 8 & Spotted Dove & $\mathrm{H}$ & 0.031 \\
\hline 9 & Eurasian Tree Sparrow & $\mathrm{H}$ & 4.054 \\
\hline
\end{tabular}

5 Scientific name: Eurasian Tree Sparrow Passer montanus, Spotted Dove

$6 \quad$ Streptopelia chinensis, Red Collared-Dove Streptopelia tranquebarica, Light-vented

7 Bulbul Pycnonotus sinensis

8

9 

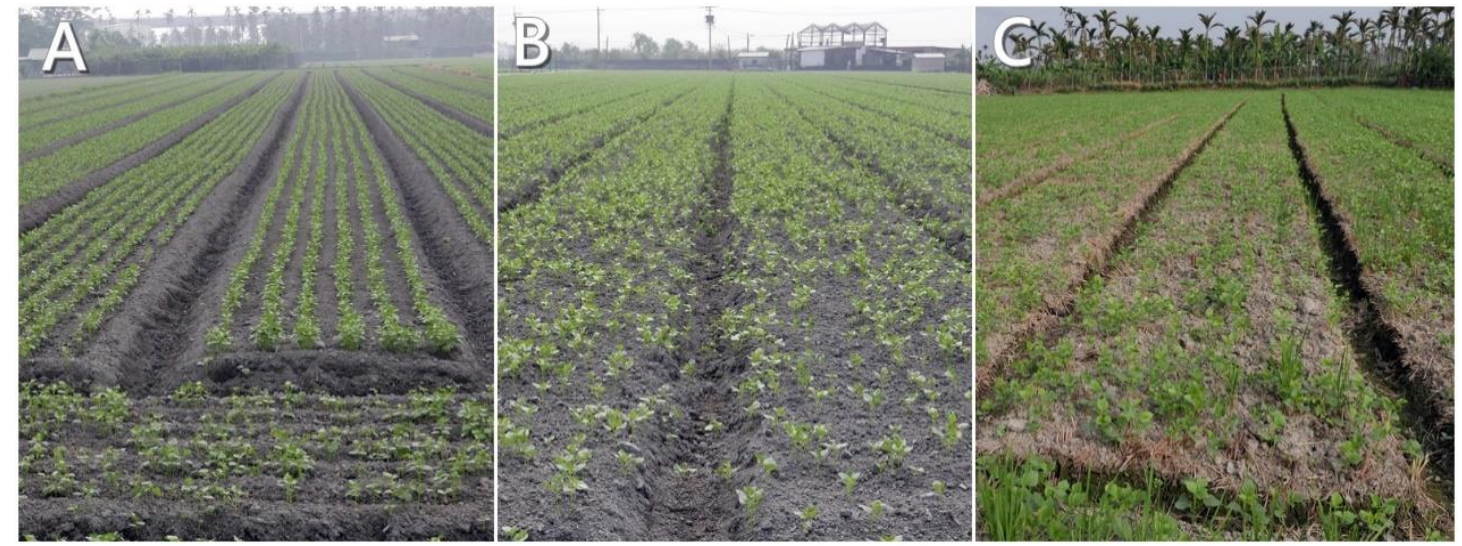

13 Fig. A1.1 Three different seeding methods of Red Bean in south Taiwan: A) large seed 14 drill, B) seeding and plowing with small cultivator, and C) broadcast seeding without 15 plowing (rice stalks still exist).

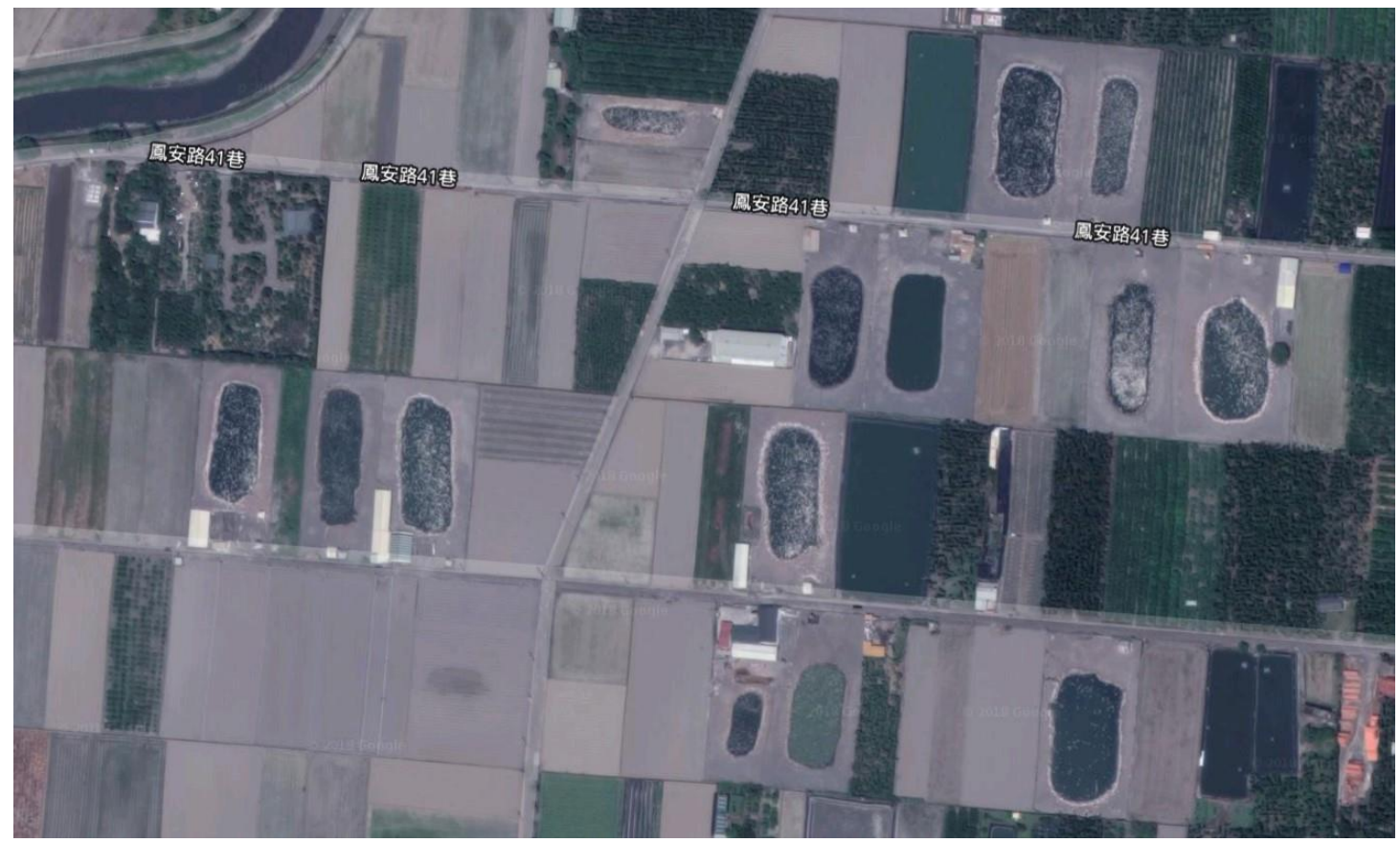

18 Fig. A1.2 Satellite imagery $(22.569661,120.500485)$ of duck farms and adjoining Red 19 Bean farms (light gray fields). The area of one field is usually between 0.3-0.6 ha. 


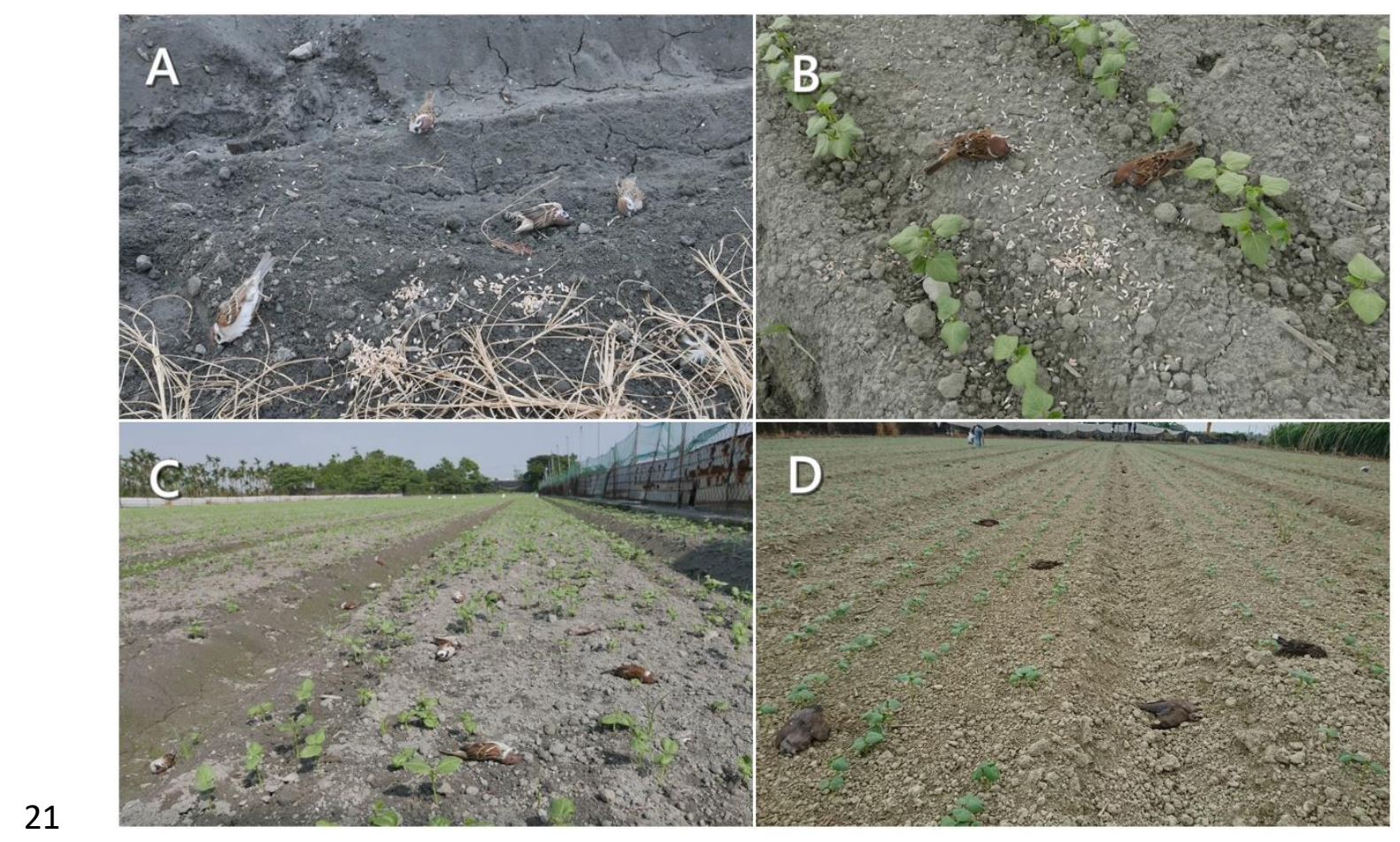

22 Fig. A1.3 A) \& B) The poisoned baits used to control bird damage were usually rice 23 or corn. C) \& D) The dead birds in Red Bean farms were mostly Eurasian Tree 24 Sparrows (Passer montanus) and Columbidaes. 